\title{
RESEARCH OF IMPACT OF EMOTIONAL MOTIVATORS ON CONSUMER BEHAVIOR
}

\author{
Saša Virijević Jovanović \\ Faculty of Applied Management, Economics and Finance, University \\ Business Academy, Novi Sad, Republic of Serbia \\ Ivana Jošanov Vrgović \\ Novi Sad School of Business, Novi Sad, Republic of Serbia \\ Tatjana Janovac \\ Faculty of Applied Management, Economics and Finance, University \\ Business Academy, Novi Sad, Republic of Serbia
}

\begin{abstract}
Regarding the importance of psychological processes in the consumer behavior, the article examines the influence of emotional motivators on purchase decisions in cosmetics industry. The empirical research was conducted from February to March 2020, on the sample of 125 respondents in Serbia. The participants answered the questions about the positive and negative emotions that occurred during the purchasing process. When defining the questionnaire, we started from the fact that emotions, which influence consumer behavior can be integral or incidental emotions. The aim of the study was to identify the emotions that have the strongest effect on consumers when purchasing cosmetic products. During the statistical data processing, the following techniques and methods were implemented: the descriptive statistical measures (frequencies and percentage, arithmetical midranges), the measures of variability, the correlation method. The survey indicated that the most dominant emotions that affect consumer purchasing decisions related to cosmetics products in the Republic of Serbia are positive emotions. The majority of respondents recognized hope as the most important emotion in their buying behavior.
\end{abstract}

Key words: consumer behavior; emotional motivators; purchasing; cosmetics industry; emotional buying

JEL classification: M30, M31

\footnotetext{
*sasa.virijevic@mef.edu.rs
} 


\title{
ISTRAŽIVANJE UTICAJA EMOCIONALNIH MOTIVATORA NA PONAŠANJE POTROŠAČA
}

\begin{abstract}
Sažetak: Polazeći od značaja psiholoških procesa u ponašanju potrošača, ovaj rad istražuje uticaj emocionalnih motivatora na proces odlučivanja u kupovini kozmetičkih proizvoda. Empirijsko istraživanje je sprovedeno od febrara do marta 2020. godine na uzorku od 125 ispitanika u Republici Srbiji. Ispitanici su odgovarali na pitanja o pozitivnim $i$ negativnim emocijama koje nastaju tokom procesa kupovine. Prilikom koncipiranja upitnika, pošlo se od činjenice da emocije koje utiču na ponašanje potrošača mogu biti integralne $i$ incidentalne. Cilj istraživanja bio je da se identifikuju emocije koje ostvaruju najsnažniji uticaj na potrošače pri odlučivanju o kupovini kozmetičkih proizvoda. Tokom statističke obrade podataka, primenjene su sledeće tehnike i metode: mere deskriptivne statistike (frekvencije, aritmetičke sredine), mere varijabiliteta $i$ metod korelacije. Rezultati istraživanja su ukazali da su pozitivne emocije najdominantnije emocije koje utiču na odluke potrošača o kupovini u kozmetičkoj industriji u Republici Srbiji. Većina ispitanika prepoznala je nadu kao najvažniju emociju u svom ponašanju pri kupovini.
\end{abstract}

Ključne reči: ponašanje potrošača, emocionalni motivatori, kupovina, kozmetička industrija, emocionalna kupovina

\section{INTRODUCTION}

Consumer behavior is a subfield of marketing that has been an intriguing area of research for many years. Therefore, researchers have made great effort in examining the effects of motivation on consumer behavior (Allen, 1941; Dichter, 1964; Shiffman \& Kanuk, 2007;). However, they have been particularly interested in finding the relations between emotions that determine such behavior (Poffenberger \& Barrows, 1924; Belk, 1975; Holbrook \& Hirschman, 1982; Hirschman \& Holbrook, 1982; Chaudhuri \& Buck, 1998). These kinds of interest are dating back to the second half of the nineteenth century, and the emergence of consumer psychology that was originally created with the idea to explore the impact of advertising on people. Nowadays, the emotional dimension of consumer behavior has been highly recognized in many scientific works (Barlow \& Maul, 2000; Ruth, 2001; Belk, Ger \& Askegaard, 2003; Zorfas \& Leemon, 2016).

Having in mind the importance of emotional motivators in customer behavior, the aim of this study was to explore the influence of emotions on consumers when purchasing cosmetic products. The cosmetic industry was chosen as a 
representative example in which previous research pointed out the importance of emotions in consumer buying and advertising (Cash \& Cash, 1982; Arnaud, 2009; Korichi et al., 2011; Anderlova \& Pšurny, 2020.). Furthermore, cosmetic products have the ability to stimulate three of human senses: touch, smell (fragrance), and sight (Korichi et al., 2008) which is another important aspect that affects consumer behavior. Furthermore, Aaker (1996) recognized that cosmetic brands can deliver emotional benefits through their association with multi-sensorial brand experiences.

According to a well-known statistical portal, Statista (2019), the main product categories in the global cosmetic industry are: skincare products (40\%), haircare products (20\%), make-up (12\%), perfumes (11\%) and hygiene products $(10 \%)$.

The paper analyzes different theoretical approaches and empirical studies regarding emotional motivators in consumer behavior and implies their findings in the area of cosmetic industry. The empirical research was conducted from February to March 2020, on the sample of 125 respondents in the Republic of Serbia. The study included twelve positive and negative emotions that were, according to literature review, recognized as the most common in the consumer behavior. In processing the obtained data SPSS program was used, with its functions of descriptive statistics and correlation.

\section{LITERATURE REVIEW}

From the scientific point of view consumer behavior is a discipline that involves various processes in which consumers make decisions about the products, perform purchases or use products in order to meet their needs. According to Schiffman and Kanuk (2010) it is "the behavior that consumers display in searching for, purchasing, using, evaluating, and disposing of products and services that they expect will satisfy their needs." Therefore, consumer behavior research also includes factors that influence purchasing decisions and product use. Consumer behavior is regarded as a subfield of marketing, but it is usually treated within a psychological perspective. It is an interdisciplinary scientific field that combines the findings of psychology, management, sociology, macroeconomics, demography, history, etc. An important element for understanding consumer behavior is psychological processes. According to Kotler (2012) marketing and environmental stimuli enter the consumer's consciousness, and a set of psychological processes combine with certain consumer characteristics to result in decision processes and purchase decisions. Due to the importance of psychological processes in consumer behavior, consumer psychology has emerged as a special field of science, which explores the processes involved when individuals or groups select, purchase, use, or 
dispose products, services, ideas, or experiences to satisfy needs and desires (Solomon, 2004). Psychological factors influencing consumer behavior can be divided into four categories: motivation, perception, learning as well as beliefs and attitudes. For the purposes of this study, we focused on exploring emotional motivators that affect consumer behavior.

\subsection{MOTIVATION AND CONSUMER BEHAVIOUR}

According to (Vallerand \& Thrill, 1993) motivation is defined as "the hypothetical construct used to describe the internal and/or external forces that produce the initiation, direction, intensity, and persistence of behavior". Regarding the psychological context motivation occurs when a need is aroused that the consumer wishes to satisfy (Solomon et al.,2016).

The starting point of Sigmund Freud's theory is that the motives, which affect human behavior are hidden or unconscious. He was a representative of dynamic psychology, reflecting the dynamic (changing) nature of human behavior, prescribed that man was better understood through instinctive, unconscious (Schumann, Haugtvedt \& Davidson, 2008). During the 1950s, motivational researchers attempted to apply Freudian ideas to understand the deeper meanings of marketing (Solomon, 2004). Professors Kotler and Keller (2012) have used this theory to study consumer behavior when choosing brands. They explained that someone who examines specific brands will react not only to their stated capabilities, but also to other, less conscious cues such as shape, size, weight, material, color, and brand name. In line with this approach professor Zaltman (2003) pointed out that 95 percent of customers' purchase decisions take place within the subconscious mind. Another important discovery Freud made was about human need to rationalize (Leader, 2012).

Psychologist Abraham Maslow differs biogenic and psychogenic needs. The author claimed that individuals must meet the needs at the lower levels of the pyramid before they can successfully be motivated to tackle the next levels (1943). Marketers showed interest in this perspective because it specifies types of product benefits people might be looking for, depending on the different levels of needs.

\subsection{EMOTIONAL MOTIVATORS IN CONSUMER BEHAVIOR}

Impulse purchase and emotional buying are only the top of the iceberg which presents an influence of emotional motivators on consumer behavior. A literature review indicates that the study of emotions affecting consumer behavior began in the 1970s. Oxenfeldt (1974) suggested that customers have 
both opinions and feelings toward certain stores that will influence their perceptions. Belk (1975) was among the first authors who noticed that consumer's mood influences their buying behavior. Smith and Ellsworth (1985) classified cognitive appraisals associated with fifteen common specific emotions in six dimensions such as pleasantness, certainty, self-responsibility, anticipated effort, attention and situational control. While exploring the effects of mood on consumer behavior, Cohen, Pham \& Andrade (2008) recognized the techniques that have been used to manipulate individuals' transient affective states. Martin, O'Neill, Hubbard \& Palmer (2008) analyzed the role of emotions in analyzing customer satisfaction. Solomon (2018) emphasized the importance of affect in consumer's behavior, which he described as the experience of emotionally laden states, ranging from moods to emotions. Oswald and Torres (2020) have examined the effects of advertising on consumer's emotions.

Some authors have gone a step further by determining how happiness affects customer choice and brand engagement (Bettiga \& Lamberti, 2020; Loureiro, Valette-Florence \& Valette-Florence, 2020; Bilro \& Japutra, 2019; Mogilner, Aaker \& Kamvar, 2012; Isen, Aparna \& Durlach 2004 ; Mogilner \& Aaker, 2009 ). Such surveys have found its confirmation in the practice of well-known companies, which have been designing their brand slogans in accordance with the assumption that purchase of the products can create a sense of happiness. Some of the examples are the following (Figure 1).

\begin{tabular}{ll}
\hline \multicolumn{1}{c}{ Brand } & \multicolumn{1}{c}{ Slogan } \\
\hline Coca - Cola & "Open happiness" \\
Disneyland & "The Happiest Place on Earth" \\
Heinz & "Where there's happy, it has to be Heinz" \\
Nesquik & "You can't buy happiness, but you can drink it." \\
Ben \& Jerry's & "Scoop of Happiness" \\
Nivea & "Touch of Happiness Body Wash" \\
General Mills & "Bee Happy, Bee Healthy" \\
Hershey's Chocolate & "Hershey's makes S'more happiness" \\
\hline
\end{tabular}

Figure 1. List of brand slogans related to happiness Note. Common knowledge

According to Magids, Zorfas \& Leemon (2015) hundreds of "emotional motivators" drive consumer behavior (e.g. a desire to feel a sense of belonging, to succeed in life, enjoy a sense of well-being, protect the environment or to feel secure).Their research, which included brands in dozens of categories showed 
that the most effective way to maximize customer value is to move beyond customer satisfaction and connect with customers at an emotional level (Zorfas \& Leemon, 2016). Achar, Agrawal \& Duhachek (2016) have divided emotions that affect consumer behavior in two categories: integral emotions and incidental emotions. This classification is based on the source of consumers' emotional experiences. Therefore, integral emotions on marketing stimuli are made by the companies, their advertising efforts, brands etc. On the other hand, incidental emotions arise as a result of customers' current mood states.

The most dominant classification that was considered in this paper refers to positive and negative emotions. Izard (1977) has identified 10 emotion components (interest, joy, surprise, sadness, anger, disgust, contempt, fear, shame, and guilt) that have strongly affected the theory of consumer behavior. The dominance of negative emotions was obvious in this approach. Nowadays, when analyzing the impact of emotions on consumer behavior, the researchers have been more focused on positive emotions and their effects on advertising, marketing decisions, branding etc. However, they have particularly emphasized positive emotions such as happiness, pride, hope, affiliation, peacefulness and love (Chaudhuri, 2006). On the other hand, the most common negative emotions that affect consumers are anger, disgust, envy, guilt, embarrassment, sadness, anxiety (Solomon , 2018; Bagozzi et al., 1999; Schiffman \& Wisenblit, 2015).

\subsection{EMOTIONS AND CONSUMER BEHAVIOR IN COSMETIC INDUSTRY}

Following the findings from the mentioned studies on emotional motivators in consumer behavior, marketing and psychology researchers have analyzed consumer emotions that affect purchasing decisions in the cosmetic market. According to Cash (1988) the use of cosmetic products affects not only social impressions but also self-image (for example, body image, self-perceptions, and mood states). Some approaches to the research problem considered the emotional dimension of consumer behavior in particular industry segments such as luxury cosmetics (Kang et al, 2020; Anderlova \& Pšurny, 2020.) or the perfume industry (Chebat \& Michon, 2003; Warrenburg, 2005). However, other authors have examined the emotions in the cosmetic industry regarding the context of impulse purchasing (Yang \& Lee, 2016).

One of the most influential authors who explored the subject is Arnaud Aubert, a neuroscience and psychology researcher at the University of Tours. During his research in the cosmetic industry, Aubert (2009) was particularly dealing with the effects of cosmetic products on consumer well-being, which concerns 
positive emotions. Cosmetic companies have also recognized the importance of studying emotions in consumer behavior. One of them is Chanel, which conducted an empirical research together with the cognitive psychology researcher Christelle Pêcher. In their study, they explored the effects of three different lipsticks on women's emotions and feelings (CosmeticOBSL'Observatoire des Cosmétiques, 2014) as well as consumer emotions regarding skin care products (Pêcher, 2016). However, only limited studies have abstracted particular emotions that affect consumer behavior in the industry, such as sexual attractiveness (Apaolaza-Ibáñez et al., 2010), self-esteem (Palumbo et al., 2017) or positive emotions in general (Aubert, 2009).

\section{METHODOLOGY}

The starting point in this study was the assumption that emotions constitute a significant driver in the decision making process (Loewenstein, Weber, Hsee \& Welch, 2001; Gilbert, 2006; Ekman \& Davidson, 2007; Han, Lerner \& Keltner, 2007; Keltner, Oatley \& Jenkins, 2014). This assumption was related to the theory and practice of the purchasing process, and the study of interrelation between emotional motivators and customer behavior in the cosmetics industry. In accordance to this, there have been defined the following hypotheses:

$\mathrm{HO}_{1}$ : Emotions have a significant impact on purchasing decisions related to cosmetic products.

$H a_{1}$ : Emotions do not have a significant impact on purchasing decisions related to cosmetic products.

$\mathrm{HO}_{2}$ : In the purchasing process of cosmetic products positive emotions have stronger influence on consumer decisions rather than negative emotions.

$\mathrm{Ha}_{2}$ : In the purchasing process of cosmetic products negative emotions have stronger influence on consumer decisions rather than positive emotions.

\subsection{RESEARCH SAMPLE}

The research sample included 125 participants in the Republic of Serbia. The survey was conducted online and offline. However, a higher level of respondent response (about 75\%) was achieved by direct contact. Regarding the gender, the structure of participants was the following: male $53,6 \%$, female $46,4 \%$.

The structure of participants related to their age included the scale from 18 years (Table 1$)$. The majority of respondents $(30,4 \%)$ belong to the age group of 36 to 45 years. 
Table 1

Age range of participants

\begin{tabular}{llcccc}
\hline & Frequency & Percent & $\begin{array}{c}\text { Valid } \\
\text { Percent }\end{array}$ & $\begin{array}{c}\text { Cumulative } \\
\text { Percent }\end{array}$ \\
\hline Valid & $18-25$ & 27 & 21.6 & 21.6 & 21.6 \\
& $26-35$ & 33 & 26.4 & 26.4 & 48.0 \\
$36-45$ & 38 & 30.4 & 30.4 & 78.4 \\
& $46-55$ & 20 & 16.0 & 16.0 & 94.4 \\
$55-65$ & 2 & 1.6 & 1.6 & 96.0 \\
& above 65 & 5 & 4.0 & 4.0 & 100.0 \\
\hline Total & $\mathbf{1 2 5}$ & $\mathbf{1 0 0 . 0}$ & $\mathbf{1 0 0 . 0}$ & \\
\hline
\end{tabular}

Note. Calculated by the authors.

Regarding the education level (Table 2), the majority of respondents (64\%) have a graduate degree, followed by a middle school degree $(19,2 \%)$, post graduate $(14,4 \%)$ and $\mathrm{PhD}(1,6 \%)$.

Table 2

Education level of the participants

\begin{tabular}{llrrrr}
\hline & Frequency & Percent & $\begin{array}{c}\text { Valid } \\
\text { Percent }\end{array}$ & $\begin{array}{c}\text { Cumulative } \\
\text { Percent }\end{array}$ \\
\hline Valid & Below middle school & 1 & .8 & .8 & .8 \\
Middle school & 24 & 19.2 & 19.2 & 20.0 \\
Graduate & 80 & 64.0 & 64.0 & 84.0 \\
Post Graduate & 18 & 14.4 & 14.4 & 98.4 \\
PhD & 2 & 1.6 & 1.6 & 100.0 \\
\hline Total & $\mathbf{1 2 5}$ & $\mathbf{1 0 0 . 0}$ & $\mathbf{1 0 0 . 0}$ & \\
\hline
\end{tabular}

Note. Calculated by the authors.

\subsection{METHODS OF DATA COLLECTION AND PROCESSING}

The research combines the theoretical and empirical approach in order to find the answers regarding the impact of emotional motivators on customer behavior in the cosmetics industry. The theoretical background is based on the literature review, as the most dominant descriptive method in the paper. During the statistical data processing, the following techniques and methods were implemented: the descriptive statistical measures (frequencies and percentage, arithmetical midranges), the measures of variability and the correlation technique. Pearson Correlation was applied in order to find the relations between the variables. 
The primary phase of data collection was a critical analysis of the existing literature and the results of previous research in order to define the hypotheses and to form the scientific basis on which the survey questions were developed.

The second phase of the research, in which the primary data were collected, was carried out during February and March 2020 in the Republic of Serbia. The survey was conducted online and offline. The questionnaire included Likert scale questions related to twelve most common emotions that affect purchasing decisions in cosmetics industry. It was created as a result of the synthesis of actual approaches dealing with the emotional dimension of consumer behavior, which have been proven in practice (Chaudhuri, 2006; Magids et al., 2015). Therefore, the study has included the following emotions: pride, sadness, anger, disgust, embarrassment, guilt, happiness, hope, love, peacefulness, envy and fear.

The importance of emotions was presented in the following scale $0=$ Not Important At All; 1 = Of Little Importance; 2 = Of Average Importance; $3=$ Very Important; 4 = Absolutely Essential.

In interpreting the obtained data SPSS program was used, with its functions of descriptive statistics and correlation.

\section{RESULTS}

The survey indicated that the majority of respondents recognize the significance of emotions that affect the purchasing process in cosmetics industry. Regarding the findings presented in Table 3, more than $91 \%$ of respondents consider emotions important $(62,7 \%$ very important; $28,6 \%$ absolutely essential) in their consumer behavior.

Table 3

Importance of emotions in purchasing cosmetics products

\begin{tabular}{llrrrr}
\hline & Frequency & Percent & $\begin{array}{c}\text { Valid } \\
\text { Percent }\end{array}$ & $\begin{array}{c}\text { Cumulative } \\
\text { Percent }\end{array}$ \\
\hline Valid & Of Average Importance & 10 & 7.9 & 8.0 & 8.0 \\
& Very Important & 79 & $\mathbf{6 2 . 7}$ & 63.2 & 71.2 \\
& Absolutely Essential & 36 & $\mathbf{2 8 . 6}$ & 28.8 & 100.0 \\
& Total & 125 & 99.2 & 100.0 & \\
Missing & System & 1 & .8 & & \\
\hline Total & & $\mathbf{1 2 6}$ & $\mathbf{1 0 0 . 0}$ & & \\
\hline
\end{tabular}

Note. Calculated by the authors. 
Having in mind the aim of the study, we have analyzed the importance of specific emotions in order to identify the variables that have the strongest influence on consumer decisions about cosmetics products. Figure 5 presents the importance of different emotions in purchasing cosmetics products according to the calculation of arithmetical mean and One - Sample Statistics. The findings showed that the most important emotions that affect consumers from the sample are the positive emotions: hope (mean=3.04), love $($ mean=2.92) and happiness (mean=2.77). On the other hand the lowest level of importance is related to embarrassment (mean=1.11). The highest std. deviation (1.149) is recorded in answers related to the importance of envy in purchasing. It indicates that respondent's attitudes regarding envy as an emotion in the buying process fluctuated between extreme values and varied more than in answers regarding other emotions.

Table 4

One - Sample Statistics

\begin{tabular}{|c|c|c|c|c|}
\hline & $\mathbf{N}$ & Mean & $\begin{array}{c}\text { Std. } \\
\text { Deviation }\end{array}$ & $\begin{array}{l}\text { Std. Error } \\
\text { Mean }\end{array}$ \\
\hline $\begin{array}{l}\text { The importance of pride in purchasing cosmetics } \\
\text { products }\end{array}$ & 125 & 1.61 & 1.054 & .094 \\
\hline $\begin{array}{l}\text { The importance of anger in purchasing cosmetics } \\
\text { products }\end{array}$ & 125 & 2.14 & .846 & .076 \\
\hline $\begin{array}{l}\text { The importance of sadness in purchasing cosmetics } \\
\text { products }\end{array}$ & 125 & 1.96 & .987 & .088 \\
\hline $\begin{array}{l}\text { The importance of disgust in purchasing cosmetics } \\
\text { products }\end{array}$ & 125 & 2.57 & .883 & .079 \\
\hline $\begin{array}{l}\text { The importance of embarrassment in purchasing } \\
\text { cosmetics products }\end{array}$ & 125 & 1.11 & .969 & .087 \\
\hline The importance of guilt in purchasing cosmetics products & 125 & 2.40 & .967 & .087 \\
\hline $\begin{array}{l}\text { The importance of happiness in purchasing cosmetics } \\
\text { products }\end{array}$ & 125 & 2.77 & 674 & .060 \\
\hline The importance of hope in purchasing cosmetics products & 125 & 3.04 & .797 & .071 \\
\hline The importance of love in purchasing cosmetics products & 125 & 2.92 & .502 & .045 \\
\hline $\begin{array}{l}\text { The importance of peacefulness in purchasing cosmetics } \\
\text { products }\end{array}$ & 125 & 2.39 & .608 & .054 \\
\hline The importance of envy in purchasing cosmetics products & 125 & 1.29 & 1.149 & .103 \\
\hline The importance of fear in purchasing cosmetics products & 125 & 1.38 & 1.061 & .095 \\
\hline
\end{tabular}

Note. Calculated by the authors. 
Starting from the assumption that there is a difference in consumer behavior between male and female respondents, we have analyzed their answers in order to identify the emotions that affect their decisions when buying cosmetics products. According to the findings presented in Table 5, female consumers consider three positive emotions very important in purchasing cosmetic products: love $($ mean=3.07), hope $($ mean=3.03) and happiness $($ mean=3.02). In comparison to male respondents, women participants are also affected by negative emotions such as disgust $($ mean $=2.88)$ and guilt $($ mean=2.74). On the other hand, male consumers in the sample recognize only one dominant emotion (hope; mean $=3.04$ ) that affects their decisions when buying cosmetics products.

\section{Table 5}

The importance of emotions in purchasing cosmetics products by gender

\begin{tabular}{|c|c|c|c|c|c|c|c|c|c|}
\hline & \multicolumn{3}{|c|}{ FEMALE } & \multicolumn{3}{|c|}{ MALE } & \multicolumn{3}{|c|}{ TOTAL } \\
\hline & 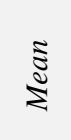 & z & 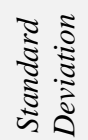 & $\underset{\Xi}{\Xi}$ & $z$ & 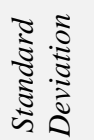 & $\frac{\tilde{z}}{\tilde{z}}$ & z & 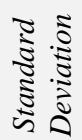 \\
\hline Proud & 2,03 & 58 & 1.025 & 1,24 & 67 & .939 & 1,61 & 125 & 1.054 \\
\hline Disgust & 2,88 & 58 & .900 & 2,30 & 67 & .779 & 2,57 & 125 & .883 \\
\hline Guilt & 2,74 & 58 & .715 & 2,10 & 67 & 1.061 & 2,40 & 125 & .967 \\
\hline Love & 3,07 & 58 & .491 & 2,79 & 67 & .478 & 2,92 & 125 & .502 \\
\hline Hope & 3,03 & 58 & 1.008 & 3,04 & 67 & .562 & 3,04 & 125 & .797 \\
\hline Happiness & 3,02 & 58 & .546 & 2,55 & 67 & .702 & 2,77 & 125 & .674 \\
\hline Fear & 1,29 & 58 & 1.108 & 1,46 & 67 & 1.020 & 1,38 & 125 & 1.061 \\
\hline Envy & 1,53 & 58 & 1.127 & 1,07 & 67 & 1.132 & 1,29 & 125 & 1.149 \\
\hline Peacefulness & 2,40 & 58 & .647 & 2,39 & 67 & .576 & 2,39 & 125 & .608 \\
\hline Embarrassment & 1,07 & 58 & .953 & 1,15 & 67 & .989 & 1,11 & 125 & .969 \\
\hline Anger & 2,34 & 58 & .785 & 1,96 & 67 & .860 & 2,14 & 125 & .846 \\
\hline Sadness & 2,38 & 58 & .791 & 1,60 & 67 & 1.001 & 1,96 & 125 & .987 \\
\hline
\end{tabular}

Note. Calculated by the authors.

In order to examine the relations between the respondent's emotions that occur in the process of purchasing cosmetics products, we have analyzed the correlation of these variables. 
Table 6

Correlations

\begin{tabular}{|c|c|c|c|c|c|c|c|c|c|c|c|c|c|c|}
\hline & & 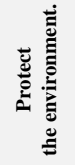 & $\bar{E}$ & 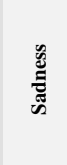 & 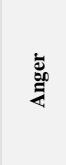 & 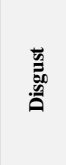 & 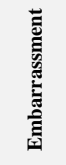 & 閍 & 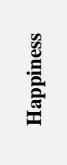 & : & ڤัٌ & 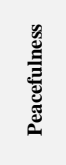 & 离 & 氞 \\
\hline \multirow{3}{*}{$\begin{array}{l}\text { Protect the } \\
\text { environmen }\end{array}$} & Pearson Cor & 1 & $.313^{* 8}$ & $.421^{* *}$ & $.205^{*}$ & $.301^{* *}$ & -.105 & .153 & $.204^{*}$ & .167 & $.230^{* *}$ & $.235^{* *}$ & .129 & $.290^{* *}$ \\
\hline & Sig. (2-tail.) & & .000 & .000 & .022 & .001 & .243 & .089 & .022 & .063 & .010 & .008 & .150 & .001 \\
\hline & $\mathrm{N}$ & 125 & 125 & 125 & 125 & 125 & 125 & 125 & 125 & 125 & 125 & 125 & 125 & 125 \\
\hline \multirow{3}{*}{ Proud } & Pearson Cor & $.313^{* * *}$ & 1 & $.582^{* *}$ & $.422^{3 *}$ & $.458^{* *}$ & .043 & $.337^{* *}$ & $.257^{* 3}$ & -.068 & $.444^{* *}$ & .078 & -.073 & $.320^{* *}$ \\
\hline & Sig. (2-tail.) & .000 & & .000 & .000 & .000 & .631 & .000 & .004 & .454 & .000 & .386 & .416 & .000 \\
\hline & $\mathrm{N}$ & 125 & 125 & 125 & 125 & 125 & 125 & 125 & 125 & 125 & 125 & 125 & 125 & 125 \\
\hline \multirow{3}{*}{ Sadness } & Pearson Cor & $.421^{* * *}$ & $.582^{* \%}$ & 1 & $.509^{* *}$ & $.480^{* *}$ & .114 & $.422^{* * *}$ & $.338^{* *}$ & .146 & $.384^{* *}$ & .080 & -.147 & $.195^{*}$ \\
\hline & Sig. (2-tail.) & .000 & .000 & & .000 & .000 & .204 & .000 & .000 & .105 & .000 & .374 & .102 & .029 \\
\hline & $\mathrm{N}$ & 125 & 125 & 125 & 125 & 125 & 125 & 125 & 125 & 125 & 125 & 125 & 125 & 125 \\
\hline \multirow{3}{*}{ Anger } & Pearson Cor & $.205^{*}$ & $.422^{* 8}$ & $.509^{* * *}$ & 1 & $.565^{* *}$ & .168 & .130 & $.197^{*}$ & .100 & $.292^{* * *}$ & $.225^{*}$ & -.176 & .134 \\
\hline & Sig. (2-tail.) & .022 & .000 & .000 & & .000 & .061 & .148 & .027 & .269 & .001 & .012 & .050 & .137 \\
\hline & $\mathrm{N}$ & 125 & 125 & 125 & 125 & 125 & 125 & 125 & 125 & 125 & 125 & 125 & 125 & 125 \\
\hline \multirow{3}{*}{ Disgust } & Pearson Cor & $.301^{* *}$ & $.458^{* 8}$ & $.480^{* *}$ & $.565^{* *}$ & 1 & .095 & $.308^{* *}$ & $.440^{* 8}$ & $.334^{* *}$ & $.504^{* *}$ & -.028 & -.045 & $.251^{* *}$ \\
\hline & Sig. (2-tail.) & .001 & .000 & .000 & .000 & & .293 & .000 & .000 & .000 & .000 & .761 & .616 & .005 \\
\hline & $\mathrm{N}$ & 125 & 125 & 125 & 125 & 125 & 125 & 125 & 125 & 125 & 125 & 125 & 125 & 125 \\
\hline \multirow{3}{*}{$\begin{array}{l}\text { Embarrass } \\
\text { ment }\end{array}$} & Pearson Cor & -.105 & .043 & .114 & .168 & .095 & 1 & .046 & .015 & .046 & .035 & $.212^{*}$ & -.176 & -.036 \\
\hline & Sig. (2-tail.) & .243 & .631 & .204 & .061 & .293 & & .607 & .864 & .608 & .697 & .017 & .050 & .686 \\
\hline & $\mathrm{N}$ & 125 & 125 & 125 & 125 & 125 & 125 & 125 & 125 & 125 & 125 & 125 & 125 & 125 \\
\hline \multirow{3}{*}{ Guilt } & Pearson Cor & .153 & $.337^{* 8}$ & $.422^{* *}$ & .130 & $.308^{* *}$ & .046 & 1 & $.292^{* *}$ & .084 & $.233^{3 *}$ & .047 & .022 & .070 \\
\hline & Sig. (2-tail.) & .089 & .000 & .000 & .148 & .000 & .607 & & .001 & .354 & .009 & .605 & .808 & .440 \\
\hline & $\mathrm{N}$ & 125 & 125 & 125 & 125 & 125 & 125 & 125 & 125 & 125 & 125 & 125 & 125 & 125 \\
\hline \multirow{3}{*}{ Happiness } & Pearson Cor & $.204^{*}$ & $.257^{* 8}$ & $.338^{* 3}$ & $.197^{*}$ & $.440^{* *}$ & .015 & $.292^{* * *}$ & 1 & $.258^{* *}$ & $.613^{* *}$ & .027 & .160 & $.514^{* * *}$ \\
\hline & Sig. (2-tail.) & .022 & .004 & .000 & .027 & .000 & .864 & .001 & & .004 & .000 & .765 & .076 & .000 \\
\hline & $\mathrm{N}$ & 125 & 125 & 125 & 125 & 125 & 125 & 125 & 125 & 125 & 125 & 125 & 125 & 125 \\
\hline \multirow{3}{*}{ Hope } & Pearson Cor & .167 & -.068 & .146 & .100 & $.334^{* *}$ & .046 & .084 & $.258^{* 8}$ & 1 & $.290^{* *}$ & .150 & .068 & .005 \\
\hline & Sig. (2-tail.) & .063 & .454 & .105 & .269 & .000 & .608 & .354 & .004 & & .001 & .094 & .454 & .956 \\
\hline & $\mathrm{N}$ & 125 & 125 & 125 & 125 & 125 & 125 & 125 & 125 & 125 & 125 & 125 & 125 & 125 \\
\hline \multirow{3}{*}{ Love } & Pearson Cor & $.230^{* * *}$ & $.444^{* 8}$ & $.384^{* *}$ & $.292^{* *}$ & $.504^{* *}$ & .035 & $.233^{* * *}$ & $.613^{* 3}$ & $.290^{* *}$ & 1 & .157 & .119 & $.404^{* *}$ \\
\hline & Sig. (2-tail.) & .010 & .000 & .000 & .001 & .000 & .697 & .009 & .000 & .001 & & .081 & .187 & .000 \\
\hline & $\mathrm{N}$ & 125 & 125 & 125 & 125 & 125 & 125 & 125 & 125 & 125 & 125 & 125 & 125 & 125 \\
\hline \multirow{3}{*}{ Peacefulness } & Pearson Cor & $.235^{* *}$ & .078 & .080 & $.225^{*}$ & -.028 & $.212^{*}$ & .047 & .027 & .150 & .157 & 1 & .140 & .114 \\
\hline & Sig. (2-tail.) & .008 & .386 & .374 & .012 & .761 & .017 & .605 & .765 & .094 & .081 & & .120 & .205 \\
\hline & $\mathrm{N}$ & 125 & 125 & 125 & 125 & 125 & 125 & 125 & 125 & 125 & 125 & 125 & 125 & 125 \\
\hline \multirow{3}{*}{ Fear } & Pearson Cor & .129 & -.073 & -.147 & -.176 & -.045 & -.176 & .022 & .160 & .068 & .119 & .140 & 1 & -.025 \\
\hline & Sig. (2-tail.) & .150 & .416 & .102 & .050 & .616 & .050 & .808 & .076 & .454 & .187 & .120 & & .779 \\
\hline & $\mathrm{N}$ & 125 & 125 & 125 & 125 & 125 & 125 & 125 & 125 & 125 & 125 & 125 & 125 & 125 \\
\hline \multirow{3}{*}{ Envy } & Pearson Cor & $.290^{* *}$ & $.320^{* *}$ & $.195^{*}$ & .134 & $.251^{* *}$ & -.036 & .070 & $.514^{* *}$ & .005 & $.404^{* *}$ & .114 & -.025 & 1 \\
\hline & Sig. (2-tail.) & .001 & .000 & .029 & .137 & .005 & .686 & .440 & .000 & .956 & .000 & .205 & .779 & \\
\hline & $\mathrm{N}$ & 125 & 125 & 125 & 125 & 125 & 125 & 125 & 125 & 125 & 125 & 125 & 125 & 125 \\
\hline
\end{tabular}

Note. Calculated by the authors.

In the research, we have also wanted to find out The results presented in Table 6 show that the highest Pearson Correlation $(\mathrm{r}=0.613)$ exists between the variables 
happiness and love. However, correlation is also present between the following variables: pride and sadness $(\mathrm{r}=0.582)$, anger and disgust $(\mathrm{r}=0.565)$, envy and happiness $(\mathrm{r}=0,514)$, sadness and anger $(\mathrm{r}=0.509)$.

In the research, we have also wanted to find out if there is a connection between consumer purchasing decisions related to the environment and their emotions during the purchase in the cosmetics industry. The findings in the Table 6 indicated that there are no strong correlations between these variables.

\section{CONCLUSION}

The aim of the study was to analyze the importance of emotions in the purchasing process in the cosmetics industry. The respondents had to declare about the importance of different positive and negative emotions that affect their purchasing decisions regarding cosmetic products. The study included twelve positive and negative emotions that were recognized as the most dominant in consumer behavior. The survey indicated that the majority of respondents $(91 \%)$ consider emotions important in their consumer behavior. When researching the importance that respondents attach to certain emotions, it was concluded that positive emotions have the greatest influence on purchasing decisions about cosmetic products. The most dominant emotions in the sample were hope $($ mean=3.04), love $($ mean=2.92) and happiness $($ mean=2.77). The lowest level of importance is related to embarrassment (mean=1.11).

The findings showed that there are differences in answers between genders. Female consumers are more affected by emotions in their purchasing process of cosmetics products. They particularly consider three positive emotions as very important: love (mean=3.07), hope (mean=3.03) and happiness (mean=3.02). The findings have also indicated the existence of negative emotions of disgust and guilt in female consumer behavior related to cosmetic products.

In order to examine the relations between the variables the statistical method of correlation was applied. According to the results the highest Pearson Correlation $(\mathrm{r}=0.613)$ is registered between the variables happiness and love.

The findings in this paper present an original contribution to the research of consumer behavior in the cosmetic industry. Bearing in mind that available literature does not provide insights regarding positive and negative emotions that affect the purchasing process of cosmetic products, this research is a useful cognitive base for further exploration. Furthermore, the findings may be applied in the marketing practice of cosmetic companies, which have to recognize the emotional dimension of consumer buying in order to achieve higher customer satisfaction. 
When interpreting the results of this research, certain limitations should be taken into consideration. The study related to cosmetic products in general, so it is expected that the results would differ if we analyzed different product categories in particular. Another limitation is the list of emotions, which was reduced to twelve variables in the study. In the future research, it would be useful to include a greater number of emotions that could be explored by different statistical methods, for example factor analysis.

\section{REFERENCES}

Aaker, D.A. (1996). Building Strong Brands. New York: Free Press.

Achar, Ch., Agrawal, N., \& Duhachek A. (2016). What we feel and why we buy: the influence of emotions on consumer decision-making. Current Opinion in Psychology, 10, 166-170.

Allen, C. N. (1941). A psychology of motivation for advertisers. Journal of Applied Psychology, 25, 378-390.

Anderlova, D., \& Pšurny M. (2020). Exploring the importance of emotions within consumer behaviour on the Czech luxury cosmetic Market. Acta Universitatis Agriculturae Et Silviculturae Mendelianae Brunensis, 68(2), 363 - 372.

Apaolaza-Ibáñez, V., Hartmann1, P., Diehl, S., \& Terlutter, R. (2010). Women satisfaction with cosmetic brands: The role of dissatisfaction and hedonic brand benefits. African Journal of Business Management, 5(3), 792-802.

Aubert, A. (2009). Bien-etre et emotions: role de l'esthetique. In: Conference: 7ème journée du Sensolier.

Bagozzi, R. P., Gopinath, M., \& Nyer, P. U. (1999). The role of emotions in marketing. Journal of the Academy of Marketing Science, 27(2) 184-206.

Barlow, J., \& Maul, D. (2000). Emotional value: Creating strong bonds with your customers. San Francisco, CA: Berrett-Koehler. 
Bettiga, D., \& Lamberti, L. (2020). Future-Oriented Happiness: Its Nature and Role in Consumer Decision-Making for New Products. Frontiers in Psychology, 11.

Belk, R. W., Ger, G., \& Askegaard, S. (2003). The fire of desire: A multi-sited inquiry into consumer passion. Journal of Consumer Research, 30(3), 326-351.

Belk, R. (1975). Situational variables and consumer behavior. Journal of Consumer Research, 2, 157-164.

Cash, T. F., \& Cash, D. W. (1982). Women's use of cosmetics: Psychosocial correlates and consequences. International Journal of Cosmetic Science, 4, 1-14.

Cash, T. F. (1988). The psychology of cosmetics: A research bibliography. Perceptual Motor Skills, 66, 445-460.

Chebat, J. C., \& Michon R. (2003). Impact of ambient odors on mall shoppers' emotions, cognition, and spending, A test of competitive causal theories. Journal of Business Research 56, 529 - 539.

CosmeticOBS-L'Observatoire des Cosmétiques (2014). Measuring the psychosocial influence of cosmetics, Congress reports https://cosmeticobs.com/en/articles/congress-reports-48/measuring-thepsychosocial-influence-of-cosmetics-2603

Chaudhuri, A., \& Buck, R. (1998). CASC_Eine Skala zur Messung Emotionaler und Rationaler Reaktionen auf Werbebotschaften. Zeitschrift fuer Sozialpsychologie, 29(2), 194-206.

Chaudhuri, A. (2006). Emotion and reason in consumer behavior. Oxford: Elsevier.

Cohen J., Pham, M. T., \& Andrade, E. B. (2008).The Nature and Role of Affect in Consumer Behavior. In Handbook of consumer psychology (297-349). New York: Taylor \& Francis Group.

Dichter, E. (1964). Handbook of consumer motivation: The psychology of the world of objects. New York: McGraw-Hill.

Ekman, P., \& Davidson, R. J. (1994). The nature of emotion: Fundamental questions. New York: Oxford University Press. 
Gilbert, D.T. (2006). Stumbling on happiness. New York: Knopf .

Han, S., Lerner, J. S., \& Keltner, D. (2007). Feelings and consumer decision making: The appraisal tendency framework. Journal of Consumer Psychology, 17, 158-68.

Hirschman, E. C., \& Holbrook, M. B. (1982). Hedonic consumption: Emerging concepts, methods and propositions. Journal of Marketing, 46(3), 92-101.

Holbrook, M. B., \& Hirschman, E. C. (1982). The experiential aspects of consumption: Consumer fantasies, feelings, and fun. Journal of Consumer Research, 9(2), 132-140.

Isen, A. M., Aparna, A. L. \& Durlach, P. (2004). An Influence of Product and Brand Name on Positive Affect: Implicit and Explicit Measures. Motivation and Emotion, 28(1), 43-63.

Izard, C. E. (1977). Human emotions. New York: Plenum.

Kang, I., He, X., \& Shin, M. M. (2020). Chinese Consumers' Herd Consumption Behavior Related to Korean Luxury Cosmetics: The Mediating Role of Fear of Missing Out. Frontiers in psychology, 11, 121.

Korichi, R., Pelle-de-Queral, D., Gazano, G., \& Aubert A. (2008). Why women use makeup: implication of psychological traits in makeup functions. International Journal of Cosmetic Science, 59(2),127-37.

Korichi, R., Pelle-de-Queral, D., Gazano, G., \& Aubert, A. (2011). Relation between facial morphology, personality and the functions of facial make-up in women. International Journal of Cosmetic Science, 33(4), 338 - 345.

Kotler, P., \& Keller, K. L. (2012). Marketing management. New Jersey: Prentice Hall.

Keltner, D., Oatley, K., \& Jenkins, J. M. (2014). Understanding emotions. Hoboken, NY: Wiley.

Leader, D. (2009). The great unknown. The Guardian. Mar 7, Retrieved from:

https://www.theguardian.com/lifeandstyle/2009/mar/07/freud-jungpsychoanalysis-behaviour-unconscious 
Loewenstein, G., Weber, E., Hsee, C., \& Welch, N. (2001). Risk as feelings. Psychological Bulletin ,127, 267-86.

Loureiro, S. M. C., Bilro, R. ,G. \& Japutra, A. (2019). The effect of consumer-generated media stimuli on emotions and consumer brand engagement. Journal of Product \& Brand Management, 29(3),387-408.

Magids, S., Zorfas, A., \& Leemon, D. (2015). The New Science of Customer Emotions. Harvard Business Review, 76, 66-74.

Martin, D., O’Neill, M., Hubbard, S., \& Palmer, A. (2008). The role of emotion in explaining consumer satisfaction and future behavioral intention. Journal of Services Marketing, 22(3), 224 - 236.

Maslow, A. H. (1943). A theory of human motivation. Psychological Review, 50, 370-396.

Mogilner, C., \& Aaker, J. (2009). The 'Time vs. Money Effect': Shifting Product Attitudes and Decisions through Personal Connection. Journal of Consumer Research, 36(7), 277-91.

Mogilner, C., Aaker, J., \& Kamvar, S. D. (2012). How Happiness Affects Choice. Journal of Consumer Research, 39(2), 429-443.

Oswald, A., \& Torres, N. (2020). Advertising Makes Us Unhappy. Harvard Business Review, Retrieved from https://hbr.org/2020/01/advertising-makes-us-unhappy

Oxenfeldt, A. (1974). Developing a favorable price-quality image. Journal of Retailing, 50, 8-14.

Palumbo, R., Fairfield, B., Mammarella, N., \& Di Domenico, A.| (2017). Does make-up make you feel smarter? The "lipstick effect" extended to academic achievement. Cogent Psychology, 4(1).

Pêcher, C., Navarro, S., Bardel, M.H., \& Mougin, D. (2016). The Emotional Power of Skincare - Chanel Parfums et Beauté. In: IFSCC Congress, Orlando, Florida.

Poffenberger, A. T., \& Barrows, B. E. (1924). The feeling value of lines. Journal of Applied Psychology, 8, 187-205. 
Ruth, J. A. (2001). Promoting a brand's emotion benefits: The influence of emotion categorization processes on consumer evaluations. Journal of Consumer Psychology, 11(2), 99-114.

Shiffman, L., \& Kanuk, L. L. (2007). Consumer Behavior. New Jersey: Prentice Hall.

Shiffman, L., \& Kanuk, L. L. (2010). Consumer Behavior. New Jersey: Pearson.

Schiffman, L. G., \& Wisenblit, J. L. (2015). Consumer Behavior. England: Pearson.

Schumann, D. W., Haugtvedt, C. P., \& Davidson, E. (2008). History of Consumer Psychology. In Handbook of consumer psychology. (p.6). New York: Taylor \& Francis Group.

Smith, C., \& Ellsworth, P. (1985) Patterns of cognitive appraisal in emotion. Journal of Personality and Social Psychology, 48(4), 813-838.

Solomon, M., Bamossy, G., Askegaard, S., \& Hogg M.K. (2006). Consumer Behavior A European Perspective. England: Prentice Hall, Pearson education.

Solomon, M. (2004). Consumer psychology. Encyclopedia of Applied Psychology. Elsevier.

Solomon, M. (2018). Consumer Behavior: Buying, Having and Being. Edinburgh: Pearson.

Vallerand, R. J., \& Thill, E. (1993). Introduction au concept de motivation [Introduction to the concept of motivation]. In R. J. \& E. E. Thills (Eds.), Introduction á la psychologie de la motivation [Introduction to the psychology of motivation] (p.3-39). Canada: Éditions Études Vivantes.

Valette-Florence, R., \& Valette-Florence, P. (2020). Effects of emotions and brand personality on consumer commitment, via the mediating effects of brand trust and attachment. Recherche et Applications en Marketing. Sage, 35(1), 84-110.

Warrenburg, S. (2005). Effects of Fragrance on Emotions: Moods and Physiology. Chemical Senses, 30(1), 248-249. 
Yang, D. \& Lee, C. W. (2016). In-store promotional mix and the effects on female consumer buying decisions in relation to cosmetic products, International Journal of Management, Economics and Social Sciences (IJMESS), 5(2), 35-56.

Zaltman, G. (2003). How Customers Think Essential Insights into the Mind of the Market. Boston, Massachusetts: Harvard Business School Press.

Zorfas, A., \& Leemon, D. (2016). An Emotional Connection Matters More than Customer Satisfaction. Harvard Business Review, Retrieved from https://hbr.org/2016/08/an-emotional-connection-mattersmore-than-customer-satisfaction

https://www.statista.com/statistics/243967/breakdown-of-thecosmetic-market-worldwide-by-product-category/

Delivered: 31.07 .2020 .

Accepted: 13.01.2021. 